\title{
SAJTARLY Inna,
}

Doctor of Philosophical Sciences,

Professor of the Department of Philosophy of Humanities

of Taras Shevchenko National University of Kyiv.

60, Volodymyrska str., Kyiv, 01033, Ukraine

E-mail: inna.saitarly@gmail.com

ORCID: https://orcid.org/0000-0001-8253-4898

\section{THE PSYCHOLOGICAL STRUCTURE OF INDIVIDUAL AS A SUBJECT MATTER OF THE POSTMODERN SOCIO-CULTURAL ANALYSIS}

This article is devoted to considering of influence the psychoanalytic anthropology on development of certain strategies in modern and postmodern philosophy of culture in the context of issue on genesis of mental structure of individual.

Keywords: psychoanalysis, structuralism, poststructuralism, civilization, civilizational approach, schizoanalyze.

Сайтарлы И. Психологическая структура личности как предмет постмодерного социокультурного анализа. Рассмотрено влияние психоаналитической антропологии на развитие некоторых стратегий в современной и постсовременной философии культуры в контексте вопроса о генезисе ментальной структуры личности.

Ключевые слова: психоанализ, структурализм, постструктурализм, цивилизация, цивилизационный подход, шизо-анализ.

Background. The need for this publication is due to there is not enough investigation of so-called theory on sociogenesis of mental structure of individual in the Ukrainian philosophical sciences. It seems very strange to us, since this theory, as we know, has made a great contribution to development of philosophical anthropology, mainly, to development of all present-day philosophy of culture, and therefore it needs of additional clarifications.

Analysis of recent researches and publications. We would like to pay most attention to encounter of two main approaches within frame of presentday theory of culture. It is referring to structuralism in its some variations, including the poststructuralism, and so-called civilizational interpretation, primarily, theoretical achievements of such outstanding scientists as Felix Guattari, Gilles Déleuz, Jean Baudrillard, Norbert Elias and so on. Moreover, one should emphasize that many today's researchers support the socio-cultural determinism, mentioned above in its grasping of human mental structure, for example, so-called theory of homo informaticus that was elaborated on the basis of postmodern critic of contemporary society and anthropological type,

(C) Sajtarly I., 2019

ISSN 1727-9313. ВICHИК КНТЕУ. 2019. № 
who correlates with it. In other words, as for the anthropological context of the postmodern philosophy of culture, one should note the dominance of the informational and communicative approach (V. Kurbatov, O. Pope, and others), according to which the postmodern human type "is the creator of new type of social-information relationships", caused by "the global communicativeinformation interaction in virtual reality" [1, p. 51].

A separate page in the comprehending of the problematic socio-genesis of mental structure of individual is to the theory of The Singularity, within the framework of which there are two main trends. One of them is to the optimistic vision of the phenomena of singularity, presented, for instance, by such outstanding scientist as M. Borders, who states about its constructive technologic, social and economic possibilities and perspectives [2]. This point of view is supported by other contemporary representatives of this theory, namely, A. Boldachev, who claims "as technological and economic singularities mean not a catastrophe, but only the exhaustion of some forms of organization of society, so a cultural singularity means not the destruction of culture, not the final aesthetic attitude of people to life, but only a change in the form of the latter" [3, p. 35].

Another reflection on this phenomenon, as a rule, is grounded on poststructuralism and itself demonstrates a critical approach. We are refereeing such recent publications as a "Social singularity: a portrait without embellishment" by I. Utyuz, O. Konovalenko, where is the issue of singularity is seen as negative consequence of postindustrial civilization, through of prism of a loneliness, that is "first of all, both as a property of a developed human nature, and as a tragedy of a person, who have forgotten how to love and did not find a unique way, and is not recognized by the world"[4, p. 50].

Meanwhile, the issue of structural dynamic of human immanence, namely, of evolution and involution of mental structures in these researches has been not investigated enough.

The aim of this research is to prove the power of psychoanalytic ideas over the modern and postmodern philosophy of culture in the context of main anthropological issues, namely the issue of mental structures of individual.

Materials and methods. A basis of this research is the theoretical and methodological achievements of postmodern philosophy in understanding and conceptualizing the main sociocultural correlates in the genesis of the psychic structure of individual. In addition to the conventional scientific principles of objectivity and historical method, the method of comparative analysis and other philosophical approaches was affected.

Results. The global crisis of contemporary culture shows about rightness of structuralism's statement concerning that a culture is the functional one, that is to say its structural core, mainly, and is to the ethic. In connection with that in a lot of today's publications the culture is mostly considered just in the same way as Freud once defined it, namely, as a system of prohibitions, or in more precise sense - a highly developed system of behavioral patterns. 
In other words, according to most of cultural strategies, the basis of social systems is to the culture. The divergence of these strategies consists in their different views on culture. So, the representatives of structuralism and post-structuralism insist that fundamental element of culture is to the institutional models of social relationships, when under the "institutionality" is comprehended as a system of normative patterns - conventional standards that is incorporated into social structure.

The civilizational approach, as a rule, is founded on the contemplativeintuitive reduction of culture to a certain religion, mentality, "ethos", language etc., which are considered to be the basic sources of cultural originality - "physiognomy", as Spengler wrote. Moreover, most of so-called civilizational interpretations of culture disregards absolutely the psychoanalytic approach altogether. But, there are the certain trends in modern and postmodern humanitarian sciences, which got an emphasized libidinal context. In other words, today it's difficult to find a trend or a theory, in which is not mentioned about psychoanalysis, especially, in such contemporary directions as structuralism, structural functionalism, feminism and poststructuralism.

The influence of psychoanalytic ideas on the modern science has led to the fact that the classical problems of investigation of consciousness or reason in modern philosophy have been replaced by the psychoanalytic topics of structuration of unconsciousness and transgression. This "replacement" has found its direct realization in post-structuralism, namely, in such strategies as "schizoanalyze" and "deconstructivism". Today, it is hardly also possible to find fundamental sociocultural study, in which one doesn't operate with such concepts as Oedipal triangle, libido, phantasm, etc. All these concepts reflect a powerful psychoanalytic impact on the development of the subject field of modern humanitarian thought.

It is remarkable that on the basis of structuralism a couple mutually complementary ways of interpreting culture have emerged. One of them is to completely critical, philosophical poststructuralism, which does not admit of the existence of culture without mechanisms of social control. It is referring to that any culture in its proper sense always realize by means of enforcing, that is poststructuralists are absolutely agree with psychoanalytic theory on repressive core of culture. The other one is a sociological approach, which points to leading role of social structure in conserving of cultural tradition. Both of them are defending the postulate about key meaning of "ethics of prohibition".

Let us start from considering of the second approach. In this regard, such outstanding scientist as a Norbert Elias gives rise to the exceptional interest, since his studies are the bright illustration of the application of structural approach, in spite of Elias determined his research as "civilizational" one, he was convinced of correctness of the structuralism way, that is to say, the "institutional" interpretation of culture.

According to Elias, term of "civilization" does not differ from term of "culture" and primarily, refers to the system of highly developed conduct norms ISSN 1727-9313. ВІСНИК КНТЕУ. 2019. 
that are fixed by a corresponding system of social relations and interdependencies. The understanding of what the term of civilization does mean, stated by Elias, is at variance with other conceptions in 20th century.

On the one hand, Elias pointes to that the word of civilization has arisen precisely the within framework of Western cultural tradition because of its aspirations to prove superiority of Western conducts standards over other ones. In other words, this term is the result of inherent in Europe snobbery that always distinguished this culture from other "civilizations" (if not considering of the Japanese tradition, which is also snobbish in a high degree). For example, in his well-knowing book "Process of civilization" Elias states that if we look at the general function of concept of civilization, in the name of which all these manners and achievements of people are designated as civilized, something very simple will immediately appear: this concept expresses the selfconsciousness of the West. One could even say - the national consciousness. With its help they try to characterize something important for Western society, what it is proud of: the state of its technology, the manners adopted in it, the development of its scientific knowledge, its worldview and much more.

On the other hand, from his view, the term of civilization is directly related and "first of all, with transformation of personal structures", which, in many Western societies, has intensified with emergence of so-called the "Courtly Society". Hence, the Process of civilization for Elias is primarily the structural changes that carried out in the direction of increasing hardening and differentiations of people's control over their affects. Elias paid very attention on such function of culture that was considered by him as major one and he defined it as the "conditioning" of human feelings and passions. According to him, this function promotes the profound transformations in the sense of "modeling" the especial sensitivity in the mental structure of person.

Analyzing the intrinsic mechanisms of internalization in the sense of mental structuring, Elias is talking about the fear less of all, which corresponds to self-preservation instinct; on the contrary, in his works, Elias insists on existence of specific social fear that is not refer to physiological fear of "bloody" punishment. This is "lack" of social recognition or fear of nonrespect: "Fear of loss or reduction of social prestige is one of the most powerful motive forces in the transformation of constraints through others into selfrestraints. It is therefore the independence of people that determines the civilizing process, imposing on it, as Elias notes, "an order sui generis". This is order more compelling and stronger that the will and reason of the individual people composing it. It is this of interweaving human impulses and strivings, this social order, which determines the course of historical change it underlies the civilized process" [5, p. 29].

It is obviously, Elias is referring to society with a highly developed system of social order and close social ties, in which so called relations are mediated by strong interdependencies. Thus, for Elias, the psychoanalytic 
principle of "lack" symbolizes no sexual or economic inferiority, as in Freudianism or in neo-Marxism, but, first of all, it refers to social inferiority in sense of the inability to gain social prestige and recognition.

The greatest finding of cultural thought of $20^{\text {th }}$ century is the discovering of unbelievable influence of socio-cultural code on the formation of mental structure, including the unconsciousness. In this connection, it is worth mentioning the more relevant for the current moment, uncompromising "metaphysics of desire" of Felix Guattari and Gilles Déleuz, in which, according to its writers, is shown a true philosophic analysis of postmodern society, named as "schizoanalyze".

The theoretical eliminating of the power of "Oedipus" in Guattari and Déleuz, consequently, of the familial power, inevitably here turns into eliminating of the culture in its ethical meaning, their outstanding tractate, named by "Anti-Oedipus. Capitalism and Schizophrenia" give rise to an ambivalent impression. On the one hand, we received the most grounded criticism of psychoanalytic "dogma", known as Oedipus complex, because, as it will find out later this element in the structure of unconsciousness is to absolutely relative. On the other hand, we see here an example the most unmasking research of post-modern culture and anthropological type that corresponding it. In other words, such type of psyche was discovered in "Anti-Oedipus", which does not dependent on Oedipus complex, that is, not related to family.

These thinkers saw a close correlation between the Oedipus construct and the system of social submission, since the Oedipus complex for them is an internal mechanism for the transformation of libidinal desire, which, from the very beginning, it is not known what it is directed at. Every social order fulfills the function of suppression, intending to "introduce" libido into system of social relationships, that is, every society a priori provokes the neurology, paranoia, or schizophrenia. Nevertheless, if Freud, for example, believed that all humanity belongs to neurotics, and therefore can be his patient, then for Guattari all current people are more "schizo" than neurotics.

Indeed, the main mechanism of today's social reproduction is to the family that is based primarily on the child's attachments. But, from the point of view of Guattari, these attachments are "artificial" that give rise to completely unnatural feelings of guilt and debt. In other words, the culture imposes a love for the parents on the child, whereas in reality his primary libido, according to the authors' deep conviction, is directed at (absolutely) impersonal objects. What is it? What do we have here? Is this a personal author's drama or a theoretical anticipation of anthropological type in future?

According to these philosophers, precisely family and culture, which are repressive, fulfill main function of production and reproduction of economic systems, which from very beginning tend to the general capitalization: "The family is indeed the delegated agent of this psychic repression insofar as it ensures a mass psychological reproduction of the economic system of society" [6, p. 118].

ISSN 1727-9313. ВІСНИК КНТЕУ. 2019. № 1 
As the Freudians maintained, in the conditions of any society one should suppress of desire, "channelize", and "encode" or "transformation" of it that is impossible without the functioning of ethics. That is why the basis of morality is the "father's complex", called Oedipus and there is no matter what way it makes suppression on desire.

Meanwhile, today we can hardly say about the existence of a patriarchal morality, and consequently, the effectiveness of the father's complex. Postmodern Western societies are distinguished by the "absence" of the old patriarchal practices. Nevertheless, the capitalist system works and realizes an unlimited desire for flows, that is, suppression is carried out by other social "agents", regardless of the family, relations in which no longer strong emotional attachments or fear of loss of parental kindness are mediated.

But, one cannot consider that Freudian and structuralism theories of culture, which partly were supported by Elias, are to the false. Rather, on the contrary. All of them convincingly proved the dependence of the people's mentality not only on a certain culture or religion and language, but namely, on behavioral culture - the culture of real practices of public life, the particularities of which is to a large extent conditioned by the development of the institutional environment, and especially, by the level of persons interdependent on each other or by "mode of relation oriented to each other interdependent people", which Elias calls the "figuration". Although some of today's authors emphasize that "term of "relation" is not enough to designate adequately the situation that Elias described and to formulate it more exactly, one would need talk of mesh" [5, p. 27].

In addition to this, Elias clarifies that he is referring to "certain mesh of interdependences, woven by individuals themselves", for example, "Courtly Society", "State" and so on. In fact, the Parson's notion of social system is leveled here by new notion of "figuration". Another very important Elias's argument is related to statement about "class character" of culture, especially, Western one, in history of which has formed two main "ethos" - aristocratic and bourgeois.

The theory on sociogenesis of mental structure of person has replaced of so-called civilizational approach to the culture, arisen in the first half of XX century and recognized in scientific "community", with its notion of mentality as a certain and relatively unchangeable character of nation or its culture. Most of representatives of this theory proved persuasively that human mind, therefore, mentality is to the relative and historically changeable, which calls into the question of general recognized Western "rationality" as a constant trait of its mentality.

Moreover, under the conditions of the post-modern era, this rationality, step by step, is replaced by the cult of affective freedom right up to triumph of total madness and absurdity. In other words, today, Western "anthropological type" can scarcely be described in the terms of mentioned by Elias "selfconstraint", "civilities" and "propriety", that is in the terms of behavioral rationality or high-level conduct culture. 
One can state that postmodernist's views are largely based on theory socio-genesis, which, as Elias reasonably remarks, means "the emphasizing of existent connection between changes in social structure and changes behaver and mental habitus of person". But, if Elias's theory is the system of concepts and argumentations that are intend to prove the evolution of human being and human society, while the most post-modern studies are the stories about profound decline of Western culture.

Indeed, as well-known in many contemporary societies, the social relationship has lost its personal context. In other words, the relationship here is no longer based on close attachments and interdependences, vice versa, they are impersonal, indifferent, "schizoid", or only functional - business one. The schizoids, as postmodernists note, orientates to only production flows, but not on face, that allowed to Guattari and Déleuz proposed an alternative approach that differs from the existential Da-sein analysis and psychoanalysis, this is the "schizoanalyze".

Probably, that is why, today, we have excess in the broadcast of the civilizational approach, which attaches great importance to language and religion in the structure of culture, but not to normative (ethics) systems. In general, recently the narrative of culture is moving into the background that let many scientists hush up the problem of decadence of traditional culture, and with it the problem of degradation of the individual. It cannot be denied that economic paranoia, today, has embraced all social fields that have affected both production and domestic life. And authors of "Anti-Oedipus" realize this, when they write about it quite directly: "God dead or not dead; the father dead or not dead; it amounts to the same, since the same psychic repression continue unabated here in the name of God or living father, there in the name of man or the dead father" [6, p. 106].

In many postindustrial societies parent's repression is to be unacceptable. What does carry out of enforcing to the normative field, "forcibly injects production into desire and conversely, it forcibly inserts desire into social production?" Guattari and Déleuz found the answer: this is the State ("Urstaat"), which is totalitarian, in the sense of its major goal to establish of total control under any person and society with some another difference in its means or institutions.

According many scientists, a referent of social control and compulsion in circumstances of late modernity is to not family, but rather impersonal and overall "institute of consumption", including the consumption of family. It does mean that to date the enforcing to work is realized without "Oedipus construct", namely, by means of virtual simulacrum of hedonistic pleasure, "the beautiful life", American dream or, as Herbert Marcuse wrote, "deferred gratification". Finally, Guattari and Déleuz themselves point to this, when they write: "the family ceases to be a unit of production and of reproduction, when the conjunction again finds in the family the meaning of a simple unit of consumption; it is father-mother that we consume" [6, p. 264].

ISSN 1727-9313. ВIСНИК КНТЕУ. 2019. № 1 
In connection with what has been said above, one can mention another critic of modernity, namely, Jean Baudrillard, who not by chance defines the postindustrial stage of capitalism as "esthetic," that is, as a system of production relations that is based both on the production of symbolic value (simulations) and the complete absence of "labor asceticism" of an industrial society, when compulsion to work is carried out by means of probable future pleasure from consumption. All this transform essentially the mental structure of man, who, today, can scarcely make effort, since here the desire is too dominated.

So-called "metaphysics of desire" has arisen on the basis of corresponding to it objective socioeconomic and anthropological grounds. Primarily, the desire, but not "spirit" or "mind", is the basic structure of human immanence in the current circumstances. Moreover, "desire" one can consider to be once more metaphysical Absolut, since we can watch its total power in everything and everywhere. Nevertheless, desire does not always depend on "illusion of lacking".

Indeed, Freudians, neo-Freudians and postmodernists are right when they all say about the mental structure of a person as determined by the dominant system of social relationships. In other words, the intrinsic structure of "lack" is the artificial structure, which fulfills the function of specific "navigator" within desire, that may be absent in nature, as in nature, there is not any need for psychical attachment nor money or "phallus cult" and so on - all those are "simulacrums", which were created to realize and maintains of dominated socio-economic order totally.

Consequently, institutions of culture, namely, matrimonial ones, depend on how much the society as a whole need them, or does not need them, as far as it is capable to reproduction itself on other grounds, for instance, on the basis of economic relations and interdependences.

On the one hand, the authors of "Anti-Oedipus" are quite right, when point to impossibility of effectiveness of the cultural traditional in conditions of postmodern formation, because past cultural tradition is grounded on system of moral attitudes a priory, that is, on the system of libidinal suppression by means of taboos and ethical restrictions. For postmodern mode of production, that is based on production paranoia and that has grown to the production of desire, past culture is even dangerous, because it does prohibit many things. Postmodern culture by not chance was named as "orgiastic" one (Baudrillard) and most of postmodernists state about the current end or "death" of past culture in modern societies. They criticize traditional culture, which is an obvious absurd; because they criticize what does not really exist, both in the terms of highly developed conduct norms, profoundly analyzed by Elias or in the form of moral imperatives, which were subject matter of direct scientific interest from side of whole classic philosophy. Poststructuralists are too passionate in statement about the cruelty of culture, whose place, at present, belongs to the economy, which is perhaps no less cruel than the culture of the past. 
These thinkers do not distinguish between culture itself and its institutes. When the postmodernists state, that culture is "forcibly injecting" social production into desire, they mean only one aspect of culture and don't mention another way of internalization than "the Inscribing Socius, which marks bodies", for instance, the high level of interdependence in certain groups, human relationships to each other in the family, corporation, etc.

In fact, postmodernists have not overcome Nietzsche's logic regarding the fact that without fear of punishment there is no morality, hence no culture. They absolutely agree with Freud's assumption about that "the hate is older than love", and that the love with its certain moral obligations is the artificial invention of Western culture, that is a relative feeling. This is true, if refer to romantic standard. But, we wonder if really the child's attachments are to the artificial, on the foundation of which Freud, for example, had built his doctrine of Oedipus complex, moral duty and guilt, that is these attachments also product of "long-term of civilizing process".

Conclusion. Thus, as a founder of theory of sociogenesis, Elias in his reflections on origin of Courtly Forms of Conduct as the high standards of behavioral culture, reached to the conclusion that independently to repressive system, people are woven together in the long-term process of sociostructural changes, that the culture is primarily the long-term process of changes in human behavior under influence the social figurations people form together, which effect on them no less than repressions. In other words, it is the system of social interdependence civilizes human behavior speech, lives, taste and so on, that is directly involved in the society structure and its transformations. That is why postmodern criticism of culture is a clear exaggeration. Culture is not only repressive, but also is civilizing process that models and essential transforms intrinsic structure of individual that can be actualized without "bloody acts", that is by means of "mesh" of person interdependences. Nevertheless, in the conditions of postmodern society it seems to be impossible or unlikely.

\section{REFERENCES}

1.Kurbatov V. I., \& Papa, O. M. (2017). "HOMO INFORMATICUS - the man of information age: significant traits". Gumanitarnye, social'no-jekonomicheskie i obshhestvennye nauki - Humanitarian, socio-economic and social Sciences, 1, 46-51 [in English].

2.Borders, M. (2018). The Social Singularity. A Decentralist Manifesto. SOCIAL EVOLUTION. Retrieved from https://www.amazon.com/kindle/dp/B07DDPVCM1/ ref=rdr_kindle_ext_eos_detail [in English].

3. Boldachev, A. V. (2016). Finita lja istorija. Politiko-kul'turno-jekonomicheskaja singuljarnost' kak absoljutnyı krizis civilizacii. Optimisticheskǐ vzgljad v budushhee. Singuljarnost'. Obrazy "postchelovechestva" [Finita la story. Political, cultural and economic singularity as an absolute crisis of civilization. An optimistic look into the future. Singularity. Images of "posthumanism"]. Moscow: Algoritm [in Russian].

ISSN 1727-9313. ВІСНИК КНТЕУ. 2019. № 1 
4. Утюж, І., \& Коноваленко, О. (2018). Соціальна сингулярність: портрет без прикрас [Social singularity: a portrait without decoration]. Science Revue, 8 (15), September, 48-51[in Ukrainian].

5. KORTE, H. (2001). Perspectives on a Long Life: Norbert Elias and the Process of Civilization / Herbert Elias and Human interdependencies. Mc Gill Queen's University Press. Edited by Thomas Salumants [in English].

6. Deleuze, G. \& Guattari, F. (1983). Anti-Oedipus. Capitalism and Schizophrenia. [Translated be R. Hurley, M. Seem and Helen R. Lane] [in English].

The article submitted to editor's office on 24.09.2018.

Сайтарли І. Психологічна структура особистості як предмет постмодерного соціокультурного аналізу.

Постановка проблеми. Актуальність статті обумовлена недостатнім вивченням так званої теорії про сочіальний генезис психічної структури особистості в украӥнських філософських науках. Проте саме ия теорія суттєво вплинула на розвиток філософської антропологї, переважно, розвиток усісї сучасної філософії культури, відтак, вона потребує додаткових уточнень.

Аналіз останніх досліджень і публікацій. Розглянуто зіткнення двох основних підходів у межах сучасної теорії культури - структуралізм у його окремих варіаціях (враховуючи постструктуралізм) і так звану циивілізаційну інтерпретацію, насамперед, теоретичні досягнення таких видатних науковців, як Ф. Гваттарі, Ж. Дельоз, Ж. Бодріяр, Н. Еліас та ін. Більшість сучасних дослідників підтримують означений соціокультурний детермінізм у поясненні ментальної структури людини, наприклад, теорія hoто-informaticus, яка розроблена на основі постмодерної критики сучасного суспільства та пов'язаного з ним антропологічного типу. В антропологічному контексті постсучасної філософії культури домінує інформаційнокомунікативний підхід (В. Курбатов, О. Папа та ін.), згідно з яким постмодерна "людина є творием нового типу соиіально-інформаційних відносин", обумовленого "глобальною комунікативно-інформаційною взаємодією у віртуальній реальності". Окремою сторінкою в осягненні проблематики соціогенези ментальних структур особистості $\epsilon$ теорія сингуляності, в межах якої сформувалися два головних підходи. Один з них є оптимістичним баченням явища сингулярності, щзо представлене, наприклад, таким відомим науковием, як М. Бордерс, який стверджував про його конструктивні, технологічні, сочіальні та економічні можливості й перспективи. Інші розмисли довкола ичього явища трунтуються на постструктуралізмі та самі по собі демонструють критичність. Йдеться про нещзодавні публікаиії на прикладі статті I. Утюж та О. Коноваленко "Соціальна сингулярність: портрет без прикрас", у якій питання про сингулярність розглядається через зростання самотності як негативний наслідок постіндустріальної изивілізаиії.

Однак питання структурної динаміки людської іманентності, а саме еволюиії та інволюиї психічних структур у цихх розвідках досліджено недостатньо.

Метою иъього дослідження $\epsilon$ доведення панування психоаналітичних ідей у сучасній та постсучасній філософії культури в контексті основних антропологічних питань, а саме питання про психічні структури особистості.

Матеріали та методи. Основою иьього дослідження є теоретичні та методологічні досягнення постмодерної філософії у розумінні та концептуалізацї основних соціокультурних корелятів щңодо тенези психічної структури особистості. Крім загальноприйнятих наукових принципів об'єктивності та історичного методу, застосовано методи порівняльного аналізу та інші філософські підходи.

Результати дослідження. Філософський аналіз деяких постмодерних текстів демонструє, що їх автори так $і$ не здолали ніщщеанську логіку стосовно того, щяо без страху перед покаранням мораль не є можливою, як не є можливою культура. 
Постмодерністи абсолютно погоджуються з припущенням Фрейда про те, що "ненависть старма за любов", і що любов з ї̈ певними моральними зобов'язаннями $\epsilon$ штучним винаходом західної культури, відтак, відносним почуттям. Це правда, якщо звернутися до романтичного стандарту. Але ми задаємось питанням, а чи дійсно дитячі прихильності є штучними, на підставі яких Фрейд, наприклад, створив своє вчення про Едипів комплекс, моральний обов'язок і провину, тобто щео изі прихильності є також продуктом довготривалого цчивілізаційного процесу.

Висновки. Постмодерна критика культури є явним перебільшенням. Культура є не тільки репресивним, але також ичивілізаційним процесом, за якого усталені в ній поведінкові моделі перетворюють внутрішню структуру особистості, що може бути реалізованим $i$ поза "кривавими виставами", тобто за допомогою "мереж" взаємозалежності людей між собою. Однак за умов постмодерного суспільства ије виглядає малоймовірним.

Ключові слова: психоаналіз, структуралізм, постструктуралізм, цивілізація, цивілізаційний підхід, шизоаналіз.

\section{ЛІІІІН Микола,}

к. філос. н., доцент, доцент кафедри філософських та соціальних наук Київського національного торговельно-економічного університету вул. Кіото, 19, м. Київ, 02156, Україна

E-mail:pinli@ukr.net ORCID: http://orcid.org/0000-0003-0940-088X

\section{ТВОРЧІСТЬ ТА КРЕАТИВНІСТЬ: СПОСОБИ ЛЮДСЬКОГО ІСНУВАННЯ}

Розглянуто співвідношення креативності та творчості в контексті соціальноекономічних проиесів сучасності. Творчість та креативність досліджено як два способи репрезентації сутнісних сил людини. Доведено, щзо творчість є всезагальною формою входження людини у світ культури. Натомість креативність є способом самореалізації сучасного індивіда в умовах трансформації економічної системи в кінці XXна початку XXI cm. Розглянуто деякі міфологічні упередження щзодо творчості.

Ключові слова: творчість, креативність, економіка, традиція, міфи творчості, розвиток людини.

(C) Ліпін М., 2019

ISSN 1727-9313. ВІСНИК КНТЕУ. 2019. № $1=79$ 